\title{
The Recreational Drug Ecstasy Disrupts the Hypothalamic-Pituitary-Gonadal Reproductive Axis in Adult Male Rats
}

\author{
Sarah M. Dickerson ${ }^{a}$ Deena M. Walker ${ }^{b}$ Maria E. Reveron ${ }^{a}$ \\ Christine L. Duvauchelle ${ }^{a, b}$ Andrea C. Gore ${ }^{a-c}$ \\ ${ }^{a}$ Division of Pharmacology and Toxicology and Institutes for ${ }^{b}$ Neuroscience and ${ }^{c}$ Cell and Molecular Biology, \\ The University of Texas at Austin, Austin, Tex., USA
}

\section{Key Words}

Ecstasy $(M D M A) \cdot$ Gonadotropin-releasing hormone •

Testosterone $\cdot$ Endocrine disruption $\cdot$ Male reproduction

\begin{abstract}
Reproductive function involves an interaction of three regulatory levels: hypothalamus, pituitary, and gonad. The primary drive upon this system comes from hypothalamic gonadotropin-releasing hormone (GnRH) neurosecretory cells, which receive afferent inputs from other neurotransmitter systems in the central nervous system to result in the proper coordination of reproduction and the environment. Here, we hypothesized that the recreational drug ( \pm )-3,4-methylenedioxymethamphetamine (MDMA; 'ecstasy'), which acts through several of the neurotransmitter systems that affect GnRH neurons, suppresses the hypothalamic-pituitary-gonadal reproductive axis of male rats. Adult male SpragueDawley rats self-administered saline or MDMA either once (acute) or for 20 days (chronic) and were euthanized 7 days following the last administration. We quantified hypothalamic GnRH mRNA, serum luteinizing hormone concentrations, and serum testosterone levels as indices of hypothalamic, pituitary, and gonadal functions, respectively. The results indicate that the hypothalamic and gonadal levels of the hypothalamic-pituitary-gonadal axis are significantly altered by MDMA, with GnRH mRNA and serum testosterone
\end{abstract}

levels suppressed in rats administered MDMA compared to saline. Furthermore, our finding that hypothalamic $\mathrm{GnRH}$ mRNA levels are suppressed in the context of low testosterone concentrations suggests that the central GnRH neurosecretory system may be a primary target of inhibitory regulation by MDMA usage.

Copyright $\odot 2008$ S. Karger AG, Basel

\section{Introduction}

Recreational use of ( \pm )-3,4-methylenedioxymethamphetamine $\mathrm{HCl}$ (MDMA; 'ecstasy') is particularly popular among college students and those involved in the dance culture $[1,2]$. MDMA abusers often consume the drug at all-night dance parties because it induces a state of euphoria, increased energy, insomnia, and enhanced sensory perception. MDMA causes neurocognitive deficits in attention, verbal and nonverbal learning and memory, psychomotor speed, and executive system functioning [reviewed in 3]. Other central nervous system effects of MDMA have been reported for cognitive function [4, 5], circadian rhythms [6, 7], and thermoregulation $[8,9]$.

A preliminary version of this work was presented at the 88th Annual Meeting of the Endocrine Society, June 2006.

\section{KARGER}

Fax +4161306 1234

E-Mail karger@karger.ch

www.karger.com (c) 2008 S. Karger AG, Basel

$0028-3835 / 08 / 0882-0095 \$ 24.50 / 0$

Accessible online at:

www.karger.com/nen
Andrea C. Gore

Division of Pharmacology and Toxicology, The University of Texas at Austin PHAR-Pharmacology, 1 University Station A1915

Austin, TX 78712-0125 (USA)

Tel. +1 512471 3669, Fax +1 512471 5002,E-Mail andrea.gore@mail.utexas.edu 
The widespread and diverse actions of MDMA on brain and behavior are explained at least in part by its numerous target neurotransmitter systems [reviewed in 10]. The serotoninergic and dopaminergic systems are most strongly implicated as primary targets of MDMA action, as shown by in vivo microdialysis studies [11-14] and by in vitro and ex vivo studies $[15,16]$. In addition, MDMA stimulates norepinephrine [17-20], acetylcholine [21-23], and GABA release [24]. Thus, MDMA has potential to alter disparate nervous system functions through its multiple targets.

The impact of MDMA on reproductive neuroendocrine function and the reproductive axis has not, to our knowledge, been rigorously explored. Nevertheless, this question is biologically relevant, because the same neurotransmitter systems that control these aforementioned central nervous system actions of MDMA, including (but not limited to) serotoninergic and dopaminergic pathways, also regulate reproduction [25-27; for a review see 28]. Reproductive function in mammals is driven by about 1,000 gonadotropin-releasing hormone ( $\mathrm{GnRH})$ neurons, localized in the preoptic area and hypothalamus of rodents [28], which in turn are regulated by afferent inputs from other brain regions. This neural circuitry enables the hypothalamic GnRH cells to coordinate reproduction with other environmental and homeostatic cues. Thus, GnRH neurons, through these central afferent inputs, are a potential target of MDMA.

The objective of the present study was to assess the neuroendocrine disrupting effects of MDMA in adult male Sprague-Dawley rats as a model for reproductive effects of ecstasy usage in humans. Although our primary interest has focused on the actions of MDMA on hypothalamic GnRH neurons, we also assessed actions of MDMA on the other two levels of the hypothalamic-pituitary-gonadal (HPG) axis: serum luteinizing hormone (LH) concentrations as an index of pituitary output and sex steroid hormones as an indicator of testicular function.

\section{Materials and Methods}

MDMA

MDMA was obtained through NIDA Drug Inventory Supply and Control (National Institute on Drug Abuse, Bethesda, Md., USA), and was dissolved in $0.9 \%$ saline.

\section{Animals and Procedures}

All experimental procedures were carried out in accordance with the National Institutes of Health Guide for Care and Use of Laboratory Animals, and performed following protocols ap-

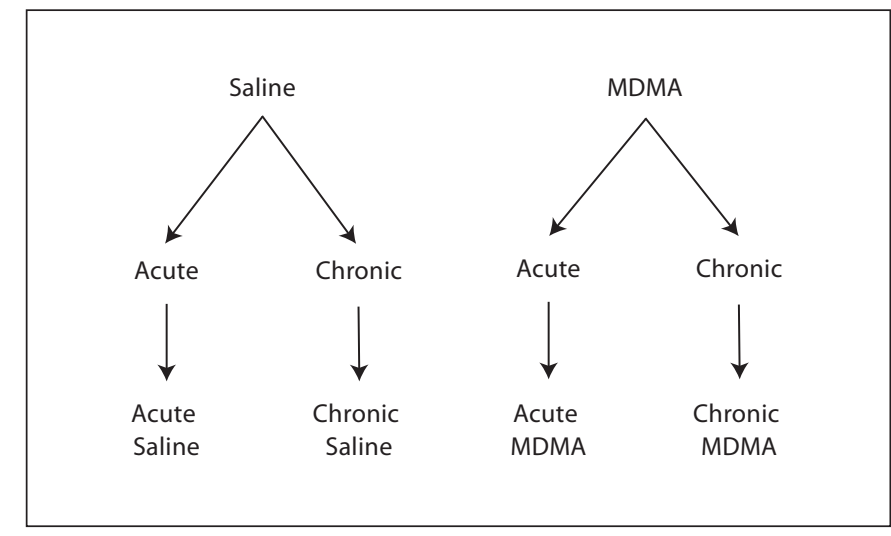

Fig. 1. Experimental model. Adult male Sprague-Dawley rats selfadministered saline or MDMA either once (acute) or ad libitum for a period of 5 days per week over a 4 -week time period, resulting in a total of 20 days (chronic). They were then euthanized 7 days following last administration, for a total of four treatment groups.

proved by the Institutional Animal Care and Use Committee at the University of Texas at Austin. Adult male Sprague-Dawley rats (250-300 g; Charles River Laboratories, Inc., Wilmington, Mass., USA) were used in this study. The experimental model used herein was to train rats to lever press for 45-mg sugar pellets (Bio-Serv, Frenchtown, N.J., USA) on a fixed-ratio 1 schedule for a minimum of 8 days, as part of a separate study seeking to enable rats to self-administer either MDMA or vehicle [8]. Additional details on animals, surgeries, and procedures are also reported by Reveron et al. [8]. In brief, rats self-administered saline or MDMA either once (acute) or for 20 days (chronic), and were euthanized 7 days following last administration, for a total of four treatment groups (fig. 1). All administration occurred intravenously, via a chronically implanted jugular catheter [for details, see 8]. The acute MDMA experimental group administered a single $3 \mathrm{mg} / \mathrm{kg}$ dose of MDMA, chosen to mimic a recreational MDMA 'binging' experience with the drug, when a large dose of the drug is ingested in one session. This dose was selected upon results of preliminary microdialysis experiments in one of our labs (C.L.D.; data not shown), which demonstrated significant increases in serotonin and dopamine in the nucleus accumbens at this dose. The chronic MDMA experimental group was designed to mimic longterm heavy use of MDMA among young people at dance clubs or 'raves', where repeated doses are taken intermittently in the same evening. Male rats were administered unit doses of MDMA (or saline control) ad libitum for 5 consecutive days for a period of 4 weeks (2-hour sessions, 5 days on, 2 days off each week for the 4 -week period). During days $1-10$ the unit dose was $1 \mathrm{mg} / \mathrm{kg} / \mathrm{in}$ jection, and during days $11-20$ the unit dose was $0.5 \mathrm{mg} / \mathrm{kg} / \mathrm{injec}$ tion [8] to optimize self-administration behavior [29]. Average daily MDMA intake for chronic MDMA animals was found to be $4 \mathrm{mg} / \mathrm{kg}$ body weight. The numbers of animals per experimental group were as follows: acute saline: 5 , chronic saline: 6 , acute MDMA: 5, chronic MDMA: 9. In the Results section, any deviation from the number of animals per group noted here represents a lost data point due to experimental error or tissue loss. 


\section{Blood and Tissue Collection}

The rats, acutely or chronically treated with MDMA or saline, were euthanized by carbon dioxide asphyxiation 7 days following the final treatment. Brains were removed and one half of the preoptic area-anterior hypothalamus (POA-AH), which contains the majority of GnRH cell bodies, was dissected out on wet ice, snap frozen within 2 min of removal on dry ice, and stored at $-80^{\circ} \mathrm{C}$ until RNA extraction. Terminal blood samples were taken, and serum was separated by centrifugation at $6,000 \mathrm{~g}$ and stored at $-80^{\circ} \mathrm{C}$ until further processing.

\section{Serum Hormone Assays}

The LH level in serum samples was measured in the laboratory of Dr. Michael Woller (University of Wisconsin-Whitewater, Whitewater, Wisc., USA) by double antibody competitive binding RIA as previously described [30,31], using reagents provided by Dr. A.F. Parlow (National Hormone and Pituitary Program at NIDDK - National Institute of Diabetes and Digestive and Kidney Diseases, Bethesda, Md., USA). The reference standard used was rat LH-RP-3. Duplicate volumes of $100 \mu \mathrm{l}$ serum were used for each sample, and three separate assays were performed. The assay sensitivity was $0.2 \mathrm{ng} / \mathrm{ml}$, the intra-assay coefficients of variability $(\mathrm{CV})$ based on duplicate samples for each assay were $2.36,4.39$, and $4.35 \%$, respectively, and the interassay CV was $7.23 \%$.

Total serum testosterone was determined in two assays using the DSL-10-4000 Active ${ }^{\circledR}$ Testosterone EIA kit (lot No. 08035-B; Diagnostic Systems Laboratories, Inc., Webster, Tex., USA), according to the manufacturer's instructions. Duplicate volumes of $50 \mu \mathrm{l}$ serum were used for each sample. The assay limit of detection was $0.04 \mathrm{ng} / \mathrm{ml}$, and the intra-assay CV based on duplicate samples for each assay were 3.11 and $5.76 \%$, respectively, and the interassay CV was $8.07 \%$.

Progesterone concentrations were determined in a single assay using the DSL-3900 Active ${ }^{\circledR}$ Progesterone coated-tube RIA kit (lot No. 07076; Diagnostic Systems Laboratories), according to the manufacturer's instructions. Duplicate volumes of $25 \mu \mathrm{l}$ serum were used for each sample. The sensitivity of the assay was 0.12 $\mathrm{ng} / \mathrm{ml}$, and the intra-assay CV was $2.3 \%$.

Estradiol concentrations were determined in a single assay using the ultrasensitive DSL-4800 double antibody RIA kit (lot No. 07076; Diagnostic Systems Laboratories), according to the manufacturer's instructions. Duplicate volumes of $200 \mu \mathrm{l}$ serum were used for each sample. The assay limit of detection was $2.2 \mathrm{pg} / \mathrm{ml}$, and the intra-assay CV based on duplicate samples for each assay was $2.83 \%$. For all assays, samples for which the CV between duplicates was $10 \%$ or greater were excluded from analysis.

\section{GnRH and Cyclophilin Gene Expression Analysis by}

\section{Real-Time PCR}

Gene expression of $\mathrm{GnRH}$ and cyclophilin, the latter an internal control [32, 33], were measured using real-time PCR with the Brilliant ${ }^{\circledR}$ qPCR kit and the MX3000 detection system (both Stratagene, La Jolla, Calif., USA). Messenger RNA from frozen POA-AH dissections of individual rats was extracted using a double detergent lysis buffer system [32]. In brief, frozen tissues were homogenized in cold lysis buffer through a 22-gauge needle, and cytoplasmic RNA was separated from nuclear RNA using a sucrose gradient. Samples were treated with proteinase $\mathrm{K}$ to remove proteins, and cytoplasmic RNA was extracted with chloroform and isopropanol, followed by precipitation at $-20^{\circ} \mathrm{C}$. The RNA was pelleted by centrifugation, washed, and resuspended in $10 \mu \mathrm{l}$ nuclease-free water (catalog No. AM9937; Applied Biosystems, Foster City, Calif., USA). Genomic contamination was removed using the DNA-free ${ }^{\mathrm{TM}}$ kit (catalog No. AM1906; Applied Biosystems), according to the manufacturer's instructions. The RNA concentration was quantified using the ND-1000 spectrophotometer (NanoDrop Technologies, Wilmington, Del., USA), and its purity was assessed using the 260:280 - and 260:230-nm ratios. All samples had 260:280 ratios between 1.8 and 2.1, and 260:230 ratios $>1.7$. The RNA integrity was assessed by examining representative samples loaded onto a $1.5 \%$ agarose gel stained with ethidium bromide. RNA ( $2 \mu \mathrm{g})$ was then converted to cDNA via RT-PCR reaction using the SuperScript ${ }^{\mathrm{TM}}$ first-strand synthesis system (catalog No. 11904-018; Invitrogen Corporation, Carlsbad, Calif., USA), according to the manufacturer's instructions. All RT reactions contained a negative control, which consisted of nuclease-free water instead of RT, to confirm absence of genomic contamination in each sample. cDNA reactions were diluted 1:5, and a $2-\mu$ l aliquot of cDNA was used as template for amplification in PCR. The primers used were 5'-TGTGCCAGGGTGGTGACTT-3' (sense) and 5'-TCAAATTTCTCTCCGTAGATGGACTT-3' (antisense) and probe $5^{\prime}$-CCACCAGTGCCATTATGGCGTGT-3' for cyclophilin [34] and 5'-CCCTTTGGCTTTCACATCCA-3' (sense) and 5'-AACAGCGGCCATCAGTTTG-3' (antisense) and probe $5^{\prime}$-ACAGAATGGAAACGATCC-3' for GnRH. PCR conditions were $95^{\circ} \mathrm{C}$ for $10 \mathrm{~min}$, followed by 50 cycles of denaturing at $95^{\circ} \mathrm{C}$ for $30 \mathrm{~s}$, annealing at $55^{\circ} \mathrm{C}$ for $60 \mathrm{~s}$, and extension at $72^{\circ} \mathrm{C}$ for $30 \mathrm{~s}$. For each sample, GnRH gene expression was normalized to cyclophilin, and relative expression was determined using the comparative CT Method [35]. RNA extracted from the POA-AH of an intact untreated male rat was used as a positive control, and was included as a standard on each assay plate. Samples were run in triplicate and analyzed in duplicate to account for pipetting errors. The mean positive control value was used as a calibrator for interplate variability. The interassay CV was $6 \%$.

\section{Statistical Analysis}

The effects of MDMA on serum hormone levels and GnRH gene expression were analyzed using two-way ANOVAs [variables: drugs (saline, MDMA) $\times$ duration (acute, chronic)] with Statview 5.0 software for Macintosh computer. Significant interactions and main effects were probed further with Fisher's protected least significant difference post hoc tests. Differences were considered significant at $\mathrm{p}<0.05$. All data are reported as mean \pm SEM unless otherwise noted.

\section{Results}

\section{Effects of MDMA on Hypothalamic GnRH Gene Expression}

GnRH gene expression was measured using real-time PCR in POA dissections. Two-way ANOVA revealed a significant main effect of drug treatment upon GnRH mRNA levels, with overall lower levels of GnRH mRNA expressed in MDMA-treated compared to saline-treated 


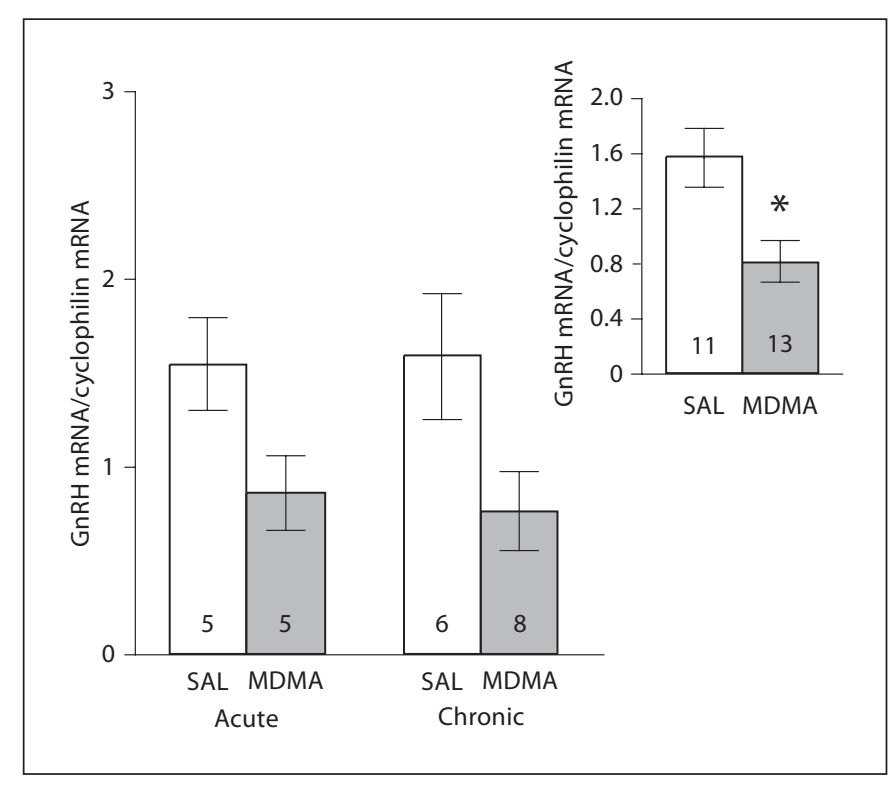

Fig. 2. Effects of acute and chronic MDMA or saline (SAL) on POA-AH GnRH mRNA levels, normalized relative to cyclophilin mRNA levels. A significant main effect of drug was detected, with MDMA rats having decreased GnRH mRNA levels compared to SAL rats. Because there were no differences in results between the acute and chronic groups, the inset shows the comparison between all MDMA and SAL rats combined for both durations of treatment. Mean \pm SEM; numbers of rats per group are shown within each column. Inset ${ }^{*} p<0.01$ compared to SAL rats.

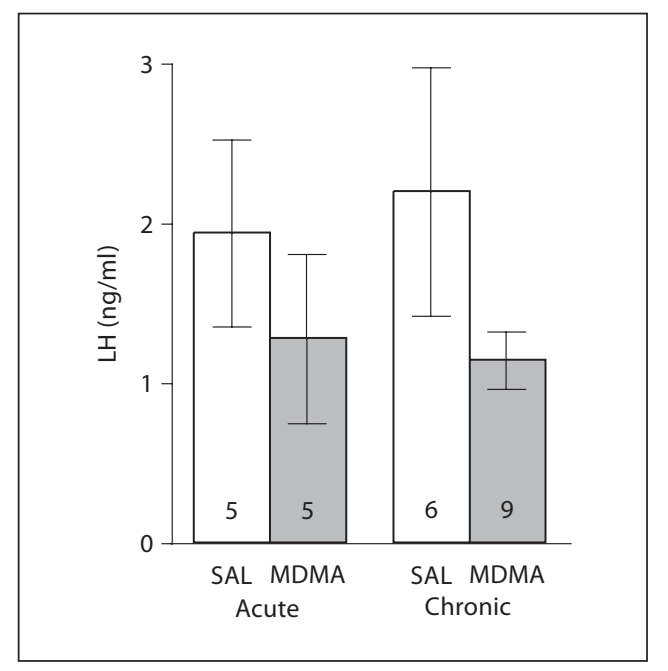

Fig. 3. Effects of acute and chronic MDMA or saline (SAL) on serum LH concentrations. No significant differences in serum LH were detected for treatment or duration, with no significant interactions of the two variables. Mean \pm SEM; numbers of rats per group are shown within each column.

Neuroendocrinology 2008;88:95-102
}

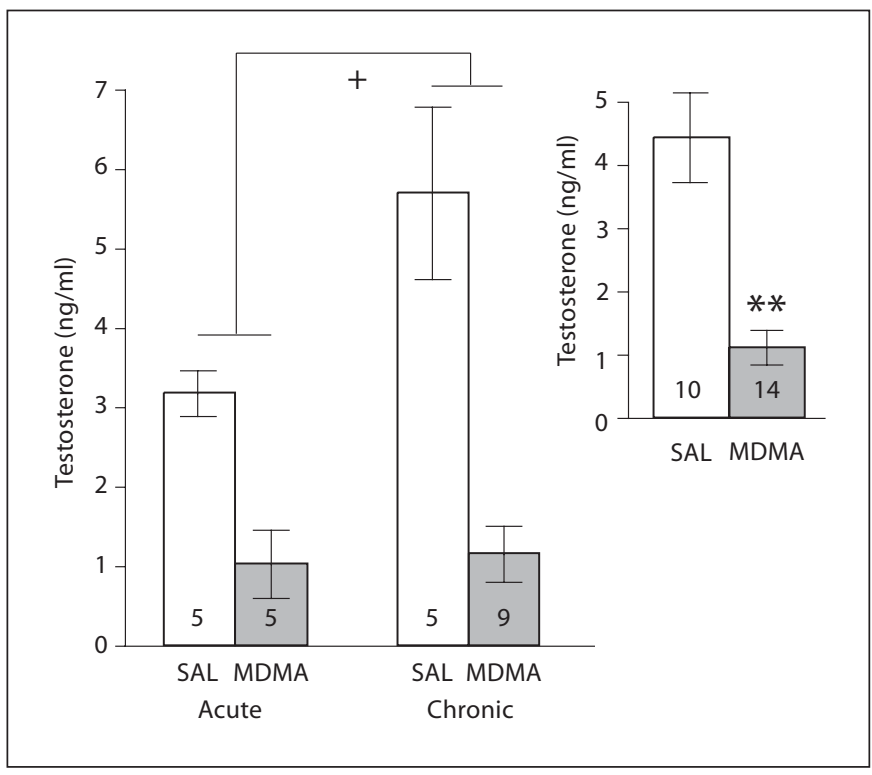

Fig. 4. Effects of acute and chronic MDMA or saline (SAL) on serum testosterone concentrations. Testosterone concentrations were significantly lower in the MDMA compared to the SAL group, as indicated in the inset. Chronic-treatment rats also had higher testosterone levels than acute-treatment rats $\left({ }^{+} \mathrm{p}<0.05\right)$. Mean \pm SEM; numbers of rats per group are shown within each column. Inset ${ }^{* *} \mathrm{p}<0.0001$ compared to SAL rats.

rats $(\mathrm{F}=8.584, \mathrm{p}<0.01$; fig. 2). No significant main effect was detected for duration of treatment (chronic vs. acute), nor were any significant interactions between the two variables observed.

\section{Effects of MDMA on Serum LH Levels}

Serum LH levels varied considerably among rats, probably due to the pulsatile nature of $\mathrm{LH}$ release [31]. Two-way ANOVA showed no significant main effect of $\operatorname{drug}(p=0.11)$ or duration $(p=0.91)$ upon LH levels, nor were any significant interactions between the two variables observed ( $\mathrm{p}=0.71$; fig. 3 ).

\section{Effects of MDMA on Serum Testosterone Levels}

A significant main effect of drug treatment was found for serum testosterone concentrations, with decreased levels in the MDMA compared to the saline group ( $\mathrm{F}=$ $33.23, \mathrm{p}<0.0001$; fig. 4). A significant main effect of duration $(\mathrm{F}=5.15, \mathrm{p}<0.05)$ on serum testosterone levels was also found, with higher testosterone levels after chronic than acute treatment (fig. 4). There was a nonsignificant trend for an interaction of treatment with duration $(\mathrm{p}=$
Dickerson/Walker/Reveron/ Duvauchelle/Gore 


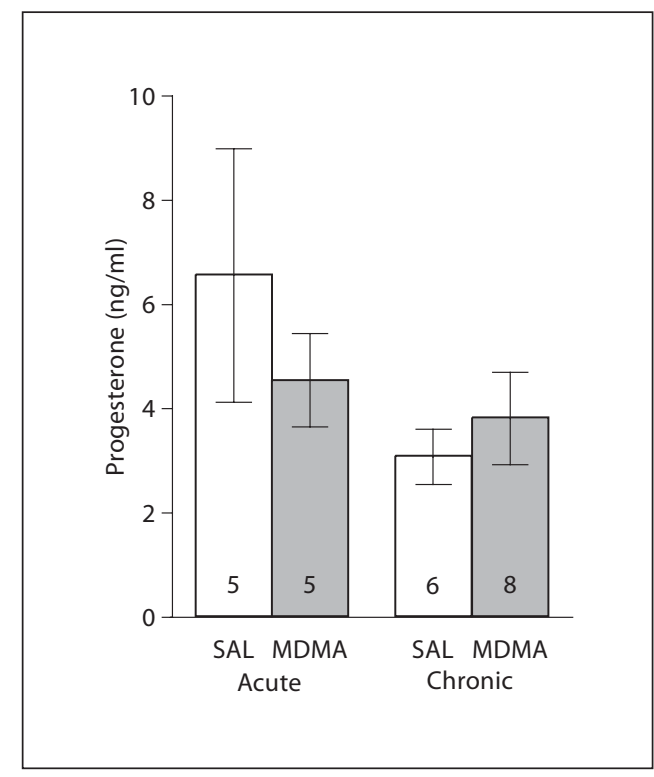

Fig. 5. Effects of acute and chronic MDMA or saline (SAL) on serum progesterone concentrations. No significant differences in serum progesterone were found for drug or duration of treatment. Mean \pm SEM; numbers of rats per group are shown within each column.

0.054), and results suggest that the effect of duration is largely due to differences among the saline-treated animals. Nevertheless, MDMA significantly suppressed serum testosterone levels at both durations compared to respective saline controls.

\section{Effects of MDMA on Serum Progesterone and}

Estradiol Levels

Serum estradiol and progesterone concentrations were measured to further assess the effect of systemic MDMA on steroid hormones. For progesterone, two-way ANOVA revealed no significant main effects of drug $(p=0.62)$ or duration $(\mathrm{p}=0.11)$, nor were any interactions between drug and duration observed ( $\mathrm{p}=0.29$; fig. 5$)$. For the estradiol assay, a high percentage of samples had a large assay $\mathrm{CV}$, and a lack of serum for repeating the assay resulted in a very small sample size that did not provide adequate statistical power for analysis. For those animals with detectable estradiol concentrations, preliminary results suggested that there were no differences among any of the groups. Estradiol concentrations $(\mathrm{pg} / \mathrm{ml})$ for the acute-saline, chronic-saline, acute-MDMA and chronicMDMA groups were $10.0 \pm 4.1,7.1 \pm 4.5,9.3 \pm 1.9$, and $10.3 \pm 4.1$, respectively (mean \pm SD due to small numbers).
Effects of MDMA on Paired Testes Weights

Paired testes were removed and weighed, with acutesaline, chronic-saline, acute-MDMA and chronic-MDMA groups having weights $(\mathrm{g})$ of $2.66 \pm 0.72,3.37 \pm 0.25$, $3.79 \pm 0.96$, and $3.25 \pm 0.46$, respectively (mean \pm SEM). Although there was no effect of treatment or duration, there was a significant interaction of these two variables $(\mathrm{p}<0.05)$, attributable to differences between acuteMDMA and acute-saline groups.

\section{Discussion}

The present study demonstrates that MDMA administered at dosages relevant to human intake [36-38] causes a significant disruption of hypothalamic and gonadal function. Specifically, and as discussed in more detail below, rats taking MDMA had a significantly lower GnRH gene expression and lower serum testosterone concentrations compared to their saline control counterparts. Because rats were euthanized 7 days after the last MDMA administration, these findings further suggest that both acute and chronic MDMA use has lasting endocrine disrupting actions on the HPG axis. Although we recognize that metabolism and secretion of MDMA vary between species [10], these results showing that MDMA disrupts reproductive neuroendocrine function in healthy adult male rats have potential relevance to humans who use MDMA even once.

The results show that MDMA administered either acutely or chronically resulted in a significant, approximately 50\% decrease in GnRH mRNA levels 7 days later compared to saline-administered rats. Pituitary LH levels were slightly lower in these same MDMA animals but this latter result did not attain significance [e.g., 31]. Because we do not know when during the LH pulse a rat was euthanized, it is possible that more careful analyses of the effects of MDMA on LH pulsatility would reveal differences between the treatment groups. In addition, our current observation that serum testosterone was profoundly suppressed in MDMA rats is consistent with decreased drive upon the testes by the serum gonadotropins. Therefore, our results showing significant decreases in GnRH mRNA and serum testosterone concentrations, together with the nonsignificant decrease in serum LH, are consistent with diminished drive from hypothalamic GnRH neurons upon the rest of the HPG axis. Moreover, we speculate that the $\mathrm{GnRH}$ neurosecretory system is the primary target for HPG axis disruption by MDMA. If the gonad were the primary target of the MDMA suppres-

Neuroendocrinology 2008;88:95-102 
sion, thereby resulting in decreased testosterone concentrations, we would predict that negative feedback upon the hypothalamus would be reduced, resulting in an increase in $\mathrm{GnRH}$ gene expression, as reported in other experimental models [39]. As this was not the case, the suppressed testosterone levels are likely due to decreased feedforward input from the hypothalamus, and subsequently the pituitary, upon the testes.

In addition to androgens, the male adrenal and testes also produce substantial levels of progesterone [40, 41], a hormone that plays a role in the sexual behavior of male rodents [42]. This hormone was assayed in the current study, with no effects of drug treatment found. We also assayed serum estradiol, and although our sample sizes were too small to perform statistics, the preliminary results suggest that there was no apparent effect of any MDMA treatment. Therefore, effects of MDMA on steroid hormones measured thus far appear to be specific to testosterone.

Although it was beyond the scope of the current study to determine which neurotransmitter systems mediate the effects of MDMA on the hypothalamic GnRH system, these are likely to be similar to those that underlie MDMA's other central nervous system actions. The two most plausible candidates are serotonin and dopamine, as they have been reported to be the primary targets of MDMA in other regions of the brain [8; reviewed in 10]. Serotonin and dopamine neurons innervate the hypothalamus, and receptors for both these neurotransmitters are expressed in the preoptic area, the location of the GnRH cell bodies [43, 44; reviewed in 28]. Serotonin agonists have been reported to be either stimulatory or inhibitory to GnRH neurons depending upon the experimental model [26, 45, 46]. A similar finding has been made for dopaminergic actions on GnRH cells [25, 47, 48]. Although it is difficult to reconcile both stimulatory and inhibitory effects of these neurotransmitter systems, they are probably best explained by there being a permissive window of normal functional activity of serotonin or dopamine, manipulations above or below which cause disruption of GnRH function. It is possible that through alterations in hypothalamic monoaminergic receptors, MDMA can influence these inputs into the $\mathrm{GnRH}$ neurosecretory system, either directly or indirectly.

This study was conducted to evaluate the impact of MDMA on the HPG axis of rats. However, we would like to note that the model of MDMA self-administration in rats is a topic of considerable controversy [49]. Several laboratories [29, 50, 51], including one of ours (C.L.D.) [8], but not others [reviewed in 49], have shown that rats and mice self-administer MDMA. Although acquisition occurs at a slower rate and supports fewer lever responses compared to other psychostimulants [49, 50, 52-55], the salient point is that our rats in the current study self-administered MDMA at levels comparable to voluntary human intake. Thus, we were able to make comparisons between animals given MDMA versus saline to determine specific effects on the reproductive axis.

The major novel finding of this study is that, to our knowledge, it provides the first evidence that MDMA disrupts the HPG axis of adult male rats and, even more specifically, that the mechanism for this effect involves the targeting of the hypothalamic-preoptic GnRH system. Our results are consistent with observations that environmental or pharmaceutical substances that disrupt monoaminergic neurotransmitter functions in the hypothalamus, including pesticides $[56,57]$ and PCBs $[58,59]$, affect $\mathrm{GnRH}$ and LH release. The popularity of MDMA among humans has increased in recent years [1], leading to concern over the potential health hazards associated with recreational drug use. The results of this study suggest that dosages approximating the recreational use of MDMA may impact the male reproductive axis.

\section{Acknowledgments}

The authors would like to acknowledge generous support from the National Science Foundation (NSF 04-615 to S.M.D.), the National Institutes of Health (T32 ES07247 to S.M.D.), the National Institute of Environmental Health Sciences (ES012272 to A.C.G.), and the National Institute on Drug Abuse (DA14640 to C.L.D.). We extend our appreciation to Dr. A.F. Parlow of the National Hormone and Pituitary Program at NIDDK for providing LH assay reagents. We thank Dr. Michael J. Woller at the University of Wisconsin-Whitewater for performing the LH assays and Esperanza Guevara for expert assistance with animal handling.

References

1 Strote J, Lee JE, Wechsler H: Increasing MDMA use among college students: results of a national survey. J Adolesc Health 2002; 30:64-72.

2 Boyd C, McCabe S, d'Arcy H: Ecstasy use among college undergraduates: gender, race and sexual identity. J Subst Abuse Treat 2003; 24:209-215.

3 Kalechstein AD, De La Garza R 2nd, Mahoney JJ 3rd, Fantegrossi WE, Newton TF: MDMA use and neurocognition: a meta-analytic review. Psychopharmacology (Berl) 2007;189:531-537. 
4 Parrott AC, Lees A, Garnham NJ, Jones M, Wesnes K: Cognitive performance in recreational users of MDMA of 'ecstasy': evidence for memory deficits. J Psychopharmacol 1998; 12:79-83.

5 Verkes RJ, Gijsman HJ, Pieters MS, Schoemaker RC, de Visser S, Kuijpers M, Pennings EJ, de Bruin D, Van de Wijngaart G, Van Gerven JM, Cohen AF: Cognitive performance and serotonergic function in users of ecstasy. Psychopharmacology (Berl) 2001; 153:196-202.

-6 Balogh B, Molnar E, Jakus R, Quate L, Olverman HJ, Kelly PA, Kantor S, Bagdy G: Effects of a single dose of 3,4-methylenedioxymethamphetamine on circadian patterns, motor activity and sleep in drug-naive rats and rats previously exposed to MDMA. Psychopharmacology (Berl) 2004;173:296-309.

7 Dafters RI, Biello SM: The effect of 3,4methylenedioxymethamphetamine ('ecstasy') on serotonergic regulation of the mammalian circadian clock mechanism in rats: the role of dopamine and hyperthermia. Neurosci Lett 2003;350:117-121.

-8 Reveron ME, Maier EY, Duvauchelle CL: Experience-dependent changes in temperature and behavioral activity induced by MDMA. Physiol Behav 2006;89:358-363.

$\checkmark 9$ Banks ML, Sprague JE, Kisor DF, Czoty PW, Nichols DE, Nader MA: Ambient temperature effects on 3,4-methylenedioxymethamphetamine-induced thermodysregulation and pharmacokinetics in male monkeys. Drug Metab Dispos 2007;35:1840-1845.

-10 Green AR, Mechan AO, Elliott JM, O'Shea E, Colado MI: The pharmacology and clinical pharmacology of 3,4-methylenedioxymethamphetamine (MDMA, 'ecstasy'). Pharmacol Rev 2003;55:463-508.

-11 Stone DM, Merchant KM, Hanson GR, Gibb JW: Immediate and long-term effects of 3,4methylenedioxymethamphetamine on serotonin pathways in brain of rat. Neuropharmacology 1987;26:1677-1683.

$\checkmark 12$ Schmidt CJ, Taylor VL: Depression of rat brain tryptophan hydroxylase following the acute administration of methylenedioxymethamphetamine. Biochem Pharmacol 1987;36:4095-4102.

13 Yamamoto BK, Spanos LJ: The acute effects of methylenedioxymethamphetamine on dopamine release in the awake-behaving rat. Eur J Pharmacol 1988;148:195-203.

- 14 Colado MI, O’Shea E, Granados R, Esteban B, Martín AB, Green AR: Studies on the role of dopamine in the degeneration of $5-\mathrm{HT}$ nerve endings in the brain of Dark Agouti rats following 3,4-methylenedioxymethamphetamine (MDMA or 'ecstasy') administration. Br J Pharmacol 1999;126:911-924.

$\checkmark 15$ Bogen IL, Haug KH, Myhre O, Fonnum F: Short- and long-term effects of MDMA ('ecstasy') on synaptosomal and vesicular uptake of neurotransmitters in vitro and ex vivo. Neurochem Int 2003;43:393-400.
16 Mlinar B, Mascalchi S, Morini R, Giachi F, Corradetti R: MDMA induces EPSP-spike potentiation in rat ventral hippocampus in vitro via serotonin and noradrenaline release and coactivation of $5-\mathrm{HT}_{4}$ and beta $\mathrm{a}_{1}$ receptors. Neuropsychopharmacology E-pub ahead of print. DOI 10.1038/sj.npp.1301512.

17 Steele TD, Nichols DE, Yim GK: Stereochemical effects of 3,4-methylenedioxymethamphetamine (MDMA) and related amphetamine derivatives on inhibition of uptake of $\left[{ }^{3} \mathrm{H}\right]$ monoamines into synaptosomes from different regions of rat brain. Biochem Pharmacol 1987;36:2297-2303.

18 Johnson MP, Conarty PF, Nichols DE: $\left[{ }^{3} \mathrm{H}\right]$ monoamine releasing and uptake inhibition properties of 3,4-methylenedioxymethamphetamine and $p$-chloroamphetamine analogues. Eur J Pharmacol 1991;200: 9-16.

19 Rothman RB, Baumann MH, Dersch CM, Romero DV, Rice KC, Carroll FI, Partilla JS: Amphetamine-type central nervous system stimulants release norepinephrine more potently than they release dopamine and serotonin. Synapse 2001;39:32-41.

20 Fitzgerald JL, Reid JJ: Interactions of methylenedioxymethamphetamine with monoamine transmitter release mechanisms in rat brain slices. Naunyn Schmiedebergs Arch Pharmacol 1993;347:313-323.

-21 Fischer HS, Zernig G, Schatz DS, Humpel C, Saria A: MDMA ('ecstasy') enhances basal acetylcholine release in brain slices of the rat striatum. Eur J Neurosci 2000;12:13851390.

22 Acquas E, Marrocu P, Pisanu A, Cadoni C, Zernig G, Saria A, DiChiara G: Intravenous administration of ecstasy (3,4-methylenedioxymethamphetamine) enhances cortical and striatal acetylcholine release in vivo. Eur J Pharmacol 2001;418:207-211.

23 Nair SG, Gudelsky GA:3,4-Methylenedioxymethamphetamine enhances the release of acetylcholine in the prefrontal cortex and dorsal hippocampus of the rat. Psychopharmacology (Berl) 2006;184:182-189.

24 Bankson MG, Yamamoto BK: SerotoninGABA interactions modulate MDMA-induced mesolimbic dopamine release. J Neurochem 2004;91:852-859.

25 Drouva SV, Gallo RV: Further evidence for inhibition of episodic luteinizing hormone release in ovariectomized rats by stimulation of dopamine receptors. Endocrinology 1977; 100:792-798.

26 Vitale ML, de las Nieves Parisi M, Chiocchio SR, Tramezzani JH: Serotonin stimulates gonadotrophin release by acting directly on the median eminence. Acta Physiol Pharmacol Latinoam 1985;35:473-479.

27 Gore AC, Terasawa E: Neural circuits regulating pulsatile luteinizing hormone release in the female guinea-pig: opioid, adrenergic and serotonergic interactions. J Neuroendocrinol 2001;13:239-248.
28 Gore AC: GnRH: The Master Molecule of Reproduction. Norwell, Kluwer Academic Publishers, 2002.

29 Schenk S, Gittings D, Johnstone M, Daniela E: Development, maintenance and temporal pattern of self-administration maintained by ecstasy (MDMA) in rats. Psychopharmacology (Berl) 2003;169:21-27.

30 Vella S, Gussick J, Woller M, Waechter-Brulla D: Modification of cell perifusion for extended study of hormone release in the rat pituitary. Methods Cell Sci 2001;23:197204.

31 Maffucci JA, Walker DM, Ikegami A, Woller MJ, Gore AC: The NMDA receptor subunit NR2b: effects on LH release and GnRH gene expression in young and middle-aged female rats, with modulation by estradiol. Neuroendocrinology 2007, E-pub ahead of print. DOI 10.1159/000111136.

32 Gore AC, Roberts JL, Gibson MJ: Mechanisms for the regulation of gonadotropin-releasing hormone gene expression in the developing mouse. Endocrinology 1999; 140: 2280-2287.

-33 Schirman-Hildesheim TD, Bar T, Ben-Aroya N, Koch Y: Differential gonadotropin-releasing hormone $(\mathrm{GnRH})$ and $\mathrm{GnRH}$ receptor messenger ribonucleic acid expression patterns in different tissues of the female rat across the estrous cycle. Endocrinology 2005; 146:3401-3408.

34 Medhurst AD, Harrison DC, Read SJ, Campbell CA, Robbins MJ, Pangalos MN: The use of TaqMan RT-PCR assays for semiquantitative analysis of gene expression in CNS tissues and disease models. J Neurosci Methods 2000;98:9-20.

35 Livak KJ, Schmittgen TD: Analysis of relative gene expression data using real-time quantitative PCR and the 2[-Delta Delta C(T)] Method. Methods 2001;25:402-408.

- 36 Peroutka SJ, Newman H, Harris H: Subjective effects of 3,4-methylenedioxymethamphetamine in recreational users. Neuropsychopharmacology 1988;1:273-277.

- 37 Mas M, Farre M, De La Torre R, Roset PN, Ortuno J, Segura J, Cami J: Cardiovascular and neuroendocrine effects and pharmacokinetics of 3,4-methylenedioxymethamphetamine in humans. J Pharmacol Exp Ther 1999;290:136-145.

38 Solowij N, Hall W, Lee N: Recreational MDMA use in Sydney: a profile of 'ecstasy' users and their experiences with the drug. $\mathrm{Br}$ J Addict 1992;87:1161-1172.

- 39 El Majdoubi M, Ramaswamy S, Sahu A, Plant TM: Effects of orchidectomy on levels of the mRNAs encoding gonadotropin-releasing hormone and other hypothalamic peptides in the adult male rhesus monkey (Macaca mulatta). J Neuroendocrinol 2000; 12:167-176.

40 Wagner CK: The many faces of progesterone: a role in adult and developing male brain. Front Neuroendocrinol 2006;27:340-359. 
-41 Kalra PS, Kalra SP: Circadian periodicities of serum androgens, progesterone, gonadotropins and luteinizing hormone-releasing hormone in male rats: the effects of hypothalamic deafferentation, castration and adrenalectomy, Endocrinology 1977; 101:18211827.

42 Phelps SM, Lydon JP, O'Malley BW, Crews D: Regulation of male sexual behavior by progesterone receptor, sexual experience, and androgen. Horm Behav 1998;34:294-302.

43 Tillet Y, Caldani M, Batailler M: Anatomical relationships of monoaminergic and neuropeptide Y-containing fibres with luteinizing hormone-releasing hormone systems in the preoptic area of the sheep brain: immunohistochemical studies. J Chem Neuroanat 1989;2:319-326.

44 Chen WP, Witkin JW, Silverman AJ: Gonadotropin releasing hormone ( $\mathrm{GnRH}$ ) neurons are directly innervated by catecholamine terminals. Synapse 1989;3:288-290.

45 Arendash GW, Gallo RV: Serotonin involvement in the inhibition of episodic luteinizing hormone release during electrical stimulation of the midbrain dorsal raphe nucleus in ovariectomized rats. Endocrinology 1978; 102:1199-1206.
46 Wada K, Hu L, Mores N, Navarro CE, Fuda H, Krsmanovic LZ, Catt KJ: Serotonin (5HT) receptor subtypes mediate specific modes of 5-HT-induced signaling and regulation of neurosecretion in gonadotropin-re leasing hormone neurons. Mol Endocrinol 2006;20:125-135.

47 Clemens JA, Tinsley FC, Fuller RW: Evidence for a dopaminergic component in the series of neural events that lead to the prooestrous surge of LH. Acta Endocrinol (Copenh) 1977;85:18-24.

48 Yoshida H, Paruthiyil S, Butler P, Weiner RI: Role of cAMP signaling in the mediation of dopamine-induced stimulation of $\mathrm{GnRH}$ secretion via D1 dopamine receptors in GT1-7 cells. Neuroendocrinology 2004;80:2-10.

49 De La Garza R 2nd, Fabrizio KR, Gupta A: Relevance of rodent models of intravenous MDMA self-administration to human MDMA consumption patterns. Psychopharmacology (Berl) 2007; 189:425-434.

50 Fantegrossi WE, Godlewski T, Karabenick RL, Stephens JM, Ullrich T, Rice KC, Woods $\mathrm{JH}$ : Pharmacological characterization of the effects of 3,4-methylenedioxymethamphetamine ('ecstasy') and its enantiomers on lethality, core temperature, and locomotor activity in singly housed and crowded mice. Psychopharmacology (Berl) 2003;166:202211.

-51 Trigo JM, Panayi F, Soria G, Maldonado R, Robledo P: A reliable model of intravenous MDMA self-administration in naïve mice. Psychopharmacology (Berl) 2006;184:212220.
2 Beardsley PM, Balster RL, Harris LS: Selfadministration of methylenedioxymethamphetamine (MDMA) by rhesus monkeys. Drug Alcohol Depend 1986;18:149-157.

53 Lamb RJ, Griffiths RR: Self-injection of 3,4methylenedioxymethamphetamine (MDMA) in the baboon. Psychopharmacology (Berl) 1987;91:268-272.

54 Lile JA, Ross JT, Nader MA: A comparison of the reinforcing efficacy of 3,4-methylenedioxymethamphetamine (MDMA, 'ecstasy') with cocaine in rhesus monkeys. Drug Alcohol Depend 2005;78:135-140.

55 Ratzenboeck E, Saria A, Kriechbaum N, Zernig G: Reinforcing effects of MDMA ('ecstasy') in drug-naïve and cocaine-trained rats. Pharmacology 2001;62:138-144.

56 Gagnaire F, Micillino JC: Effects of triadimefon on extracellular dopamine, DOPAC, HVA and 5-HIAA in adult rat striatum. Toxicology 2006;217:91-104.

57 Caudle WM, Richardson JR, Wang M, Miller GW: Perinatal heptachlor exposure increases expression of presynaptic dopaminergic markers in mouse striatum. Neurotoxicology $2005 ; 26: 721-728$.

58 Khan IA, Thomas P: Aroclor 1254 inhibits tryptophan hydroxylase activity in rat brain. Arch Toxicol 2004;78:316-320.

59 Khan IA, Thomas P: PCB congener-specific disruption of reproductive neuroendocrine function in Atlantic croaker. Mar Environ Res 2006;62(suppl):s25-s28. 